\title{
Effect of Different Cellulase and Pectinase Enzyme Treatments on Protoplast Isolation and Viability in Lilium ledebeourii Bioss.
}

\author{
Esmaeil CHAMANI' ${ }^{1 *}$, Seyyed Karim TAHAMI', Nasser ZARE², Rasool \\ Asghari-ZAKARIA², Mehdi MOHEBODINI', Daryl JOYCE ${ }^{3}$ \\ ${ }^{1}$ University of Mohaghegh Ardabili, Faculty of Agriculture, Department of Horticulture \\ Science,Ardabil,Iran; echamani@uma.ac.ir (*corresponding author) \\ ${ }^{2}$ University of Mohaghegh Ardabili, Faculty of Agriculture, Department of Agronomy and Plant Breeding, Ardabil, Iran \\ ${ }^{3}$ The University of Queensland, School of Agriculture and Food Science, Gatton, Queensland 4343, Australia
}

\begin{abstract}
For overcoming interspecific incompatibility, protoplast combination method is a proper procedure for making a new plant with desired traits. For this purpose, protoplast preparation is a first and important step. Hence, experiments were conducted to evaluate various combinations of cellulose, pectinase and their treatment times on protoplast production and protoplast viability in Lilium ledebeourii Bioss. The results of experiment revealed that the protoplast yield was significantly affected by different treatment levels. Cellulase at $4 \%$ gave the highest numbers of protoplasts at $3.71 \times 10^{5}$ protoplast $/ \mathrm{g}$ FW. Pectinase at $1 \%$ gave the highest numbers of protoplast. For treatment times, the highest yield of protoplast was with leaf explants treated for $24 \mathrm{~h}$. Analysis of variance indicated that concentration, time and three-way interaction of cellulase, pectinase and time were significant at $p<0.01$. Cellulase at $4 \%$ and pectinase at $0.2 \%$ for $24 \mathrm{~h}$ gave the highest viability. Interactions of cellulase $\times$ pectinase, cellulase $\times$ time, pectinase $\times$ time and cellulase $\times$ pectinase $\times$ treatment time were significant at $\mathrm{P} \leq 0.05$ for protoplast number. The highest and lowest protoplast numbers were produced in media containing $4 \%$ cellulase and $1 \%$ pectinase for $24 \mathrm{~h}\left(6.65 \times 10^{5}\right.$ protoplast $\left./ \mathrm{g} \mathrm{FW}\right)$ and $1 \%$ cellulase and $0.2 \%$ pectinase for $12 \mathrm{~h}$, respectively. It's concluded that, the best treatment for isolation of Lilium protoplast was $4 \%$ cellulase and $1 \%$ pectinase for $24 \mathrm{~h}$.
\end{abstract}

Keywords: cellulase, Lilium ledebeourii Bioss., pectinase, protoplast isolation, viability

\section{Introduction}

Lily flowers are admired and cultivated throughout the world. The conventional breeding of lily species has provided novel cultivars with resistance to viral diseases, tolerance for unfavorable culture conditions, and a variety of flower colours and forms (Van Tuyl et al., 1988).

Lilium ledebourii (Baker) Boiss. (Family Liliaceae) is called 'Susan-e-chelcheragh' in Persian and is the only endangered species of the Lilium genus in Iran. It has considered potential as an ornamental plant due to its large and attractive white flowers equal to those of commercial lilies (Wendelbo, 1977). L. ledebeourii can be used for breeding programs with its large raceme of 2-15 flowers. The number of plants of this species is continuously decreasing in nature because of cutting the plants and removing underground organs (Khosh-khui and Azadis, 2007). The application of in-vitro propagation techniques can offer the possibility of producing large number of uniform plants for breeding programs and field cultivation.

Protoplasts are isolated primarily by mechanical or enzymatic methods. Mechanical isolation is used only occasionally, but remains historically important. Large quantities of protoplasts can potentially be obtained with enzymatic methods. Less breakage and much less osmotic shrinkage occurs compared with mechanical methods (Torres, 1988). The success of protoplasts isolation depends on the condition of the tissue and the combination of enzymes being used (Galbraith et al., 1984; Rasheed et al., 1990; Saker et al., 1999). Effects of cell densities for protoplast development have also been reported (Kuchuk et al., 1998; Saito and Suzuki, 1999).

Several factors influence protoplast release, including the extent of cell wall thickening, temperature, duration of enzyme incubation, $\mathrm{pH}$ of the enzyme solution (Sinha et al., 2003), agitation, the nature of the osmoticum, and plasmolysis prior to enzyme digestion of source tissues in salts (Frearson, 1973). Protoplast yield and viability can be enhanced by slicing of source pre-plasmolysed tissues, manual or enzymatic removal of the epidermis, and conditioning of the donor material or its culture on media containing suitable osmoticum (Davey et al., 2004). The development of protoplast based systems has increased the utility of plants in biochemical and genetic research (Rao and Prakash, 1995), as well as providing greater prospects in genetic improvement of medicinal plants (Azad et al., 
124

2006). Technology and regeneration procedures play an increasingly significant role in plant improvement through somatic hybridization and protoplast transformation (Umate et al., 2005). Protoplasts have served as recipient hosts for DNA transformation and are required in somatic hybridization by protoplasts fusion (Stephen, 1995).

A first step towards the plant genetic manipulation and an integrated breeding programs is an efficient protocol for protoplast isolation, culture and regeneration (Duquenne et al., 2007). Leaf mesophyll cells of a wide range of plants have been used with success as a protoplast source (Saker $e t$ al., 1999). Protoplasts have been isolated from various genotypes of Petunia $\times$ bybrida (Izhar and Power, 1977; Vasil and Vasil, 1974), P. parodii, (Hayward and Power, 1975), P. inflata, P. violocea and P. axillaris (Dulieu et al., 1983; Power et al., 1976). Sink and Power (1977) reported that protoplasts of the apical region including leaf primordia proved to be superior to leaves for protoplasts isolation.

There are no published reports on the isolation and culturing of protoplasts from Lilium ledebeourii (Baker) Boiss. The objective of this study was to determine a protocol for isolation and culturing of protoplasts from Lilium ledebeourii (Baker) Boiss.

\section{Materials and methods}

Leaves of $L$. ledebeourii were used as the protoplast sources in this study. Leaf explants were cut into small pieces $1 \mathrm{~cm}$ in length and digested with 6 different enzyme solutions: (1) $4 \%$ cellulase Onozuka R-10, 1\% pectinase; (2) $4 \%$ cellulase Onozuka R10, 0.2\% pectinase; (3) 2\% cellulase Onozuka R-10, 1\% Pectinase; (4) 2\% cellulose Onozuka R-10, $0.2 \%$ pectinase; (5) $1 \%$ cellulase Onozuka R-10, 1\% pectinase, and (6) 1\% cellulase Onozuka R10, $0.2 \%$ pectinase. The enzymes were dissolved in cell protoplast washing $(\mathrm{CPW})$ salt solution containing $13 \%(\mathrm{w} / \mathrm{v})$ mannitol. The $\mathrm{pH}$ of the enzyme solutions was adjusted to 5.8 with $0.2 \mathrm{~N} \mathrm{KOH}$ or $1 \mathrm{~N} \mathrm{HCL}$. Before enzyme treatment, the explants were placed with their exposed mesophyll and palisade tissues onto $30 \mathrm{ml}$ of cell protoplast washing (CPW) with $13 \%$ mannitol solution in a $14 \mathrm{~cm}$ diameter Petri dish. Enzyme solutions were filter-sterilised through $0.2 \mu \mathrm{m}$ membrane filters (Milipore High-Flow, Sartorius, Germany). The dishes containing leaves and enzymes were sealed with Parafilm $\mathrm{m}^{\mathrm{Tw}}$ and incubated at 70 rpm for either 12 or $24 \mathrm{~h}$ on a rotary shaker in the dark at $25 \pm 2^{\circ} \mathrm{C}$. For purification, digested leaf and enzyme solutions were filtered through sterile $80 \mu \mathrm{m}$ mesh nylon sieve (Wilson Sieves, Nottingham, UK) to remove coarse and undigested materials. The collected enzyme with protoplasts was transferred to $15 \mathrm{ml}$ capacity screw-capped centrifuge tubes (Corning Ltd., New York, USA) and centrifuged at x $300 \mathrm{~g}$ for $10 \mathrm{~min}$. The pellet was re-suspended in washing solution the same as with enzyme solution but without the enzymes and then centrifuge twice at $300 \mathrm{~g}$ for $10 \mathrm{~min}$. Flotation purification was carried out with $21 \%$ sucrose at $\times 100 \mathrm{~g}$ for 5 minutes. Yields of protoplasts were determined using a double-chamber haemocytometer (Modified-Fuchs Rosenthal rulings, model B.S. 74B; Weber Scientific Internaional Ltd., Teddington, UK). The viability of protoplasts was assessed by uptake and cleavage of Trypan blue such that vital protoplasts did not show uptake. Counts of viable protoplasts were made from at least 4 fields of view from each slide and the proportion (\%) of viable protoplasts calculated. Each treatment was carried out in 3 replicates and the experiment was repeated twice. Data were analyzed using SPSS (ANOVA) Version 16.0.

\section{Results and discussion}

Analysis of variance (ANOVA) showed significant differences among different levels of cellulase, pectinase and treatment times. Using $4 \%$ cellulase produced the highest number of protoplasts, the average being $3.71 \times 10^{5}$ protoplast/gFW (Tab. 1).Among pectinase treatments, 1\% produced the highest number of protoplasts. In the case of treatment time, the highest number of protoplasts was for leaf explants treated for $24 \mathrm{~h}$. The ANOVA revealed interaction effects at $p \leq 0.05$ of cellulase $\times$ pectinase, cellulase $\times$ time, pectinase $\times$ time and cellulase $\times$ pectinase $\times$ time on protoplast number. Means comparison by Duncan's' Multiple Range Test (DMRT) revealed that the highest and lowest protoplast numbers were produced in media containing $4 \%$ cellulase and $1 \%$ pectinase for $24 \mathrm{~h}\left(6.65 \times 10^{5}\right.$ protoplast $/ \mathrm{g} \mathrm{FW}$ ) and $1 \%$ cellulase and $0.2 \%$ pectinase for $12 \mathrm{~h}\left(9.00 \times 10^{4}\right.$ protoplast/g FW), respectively. Thus, the best treatment for isolation of Lilium protoplasts was $4 \%$

Tab. 1. Analysis of variance on numbers of isolated protoplasts (protoplast/ml) from Lilium ledeoborri

\begin{tabular}{ccccc}
\hline Source of variation & Df & MS & F & $p$ value \\
\hline Cellulase & 2 & $1.877 \times 10^{11}$ & 278.47 & 0.000 \\
Pectinase & 1 & $2.091 \times 10^{11}$ & 310.26 & 0.000 \\
Time & 1 & $1.053 \times 10^{11}$ & 156.237 & 0.000 \\
CellulasexPectinase & 2 & $3.675 \times 10^{10}$ & 54.523 & 0.000 \\
Cellulasextime & 2 & $4.547 \times 10^{10}$ & 67.463 & 0.000 \\
Pectinasextime & 1 & $1.619 \times 10^{11}$ & 24.025 & 0.000 \\
CellulasexPectinasextime & 2 & $2.692 \times 10^{10}$ & 39.937 & 0.000 \\
\hline Error & 36 & $6.741 \times 10^{8}$ & & \\
\hline
\end{tabular}


cellulase plus $1 \%$ pectinase for the $24 \mathrm{~h}$ treatment time. The efficiency of protoplast isolation and culture depends on many factors, such as the enzyme mixture, the presence of growth regulator and the length of time after subculture (Assani et al, 2001). This result is similar to that of Nagao (1982) who reported that $2 \%$ cellulase plus $5 \%$ macerozyme and $0.5 \%$ mannitol at $25-20^{\circ} \mathrm{C}$ in the dark for 12-18 hr gave high isolation of protoplasts (Tab. 2). On the other hand, enzyme solution containing $4 \%(\mathrm{w} / \mathrm{v})$ cellulase (Onozuka RS), 0.5\% (w/v) Macerozyme R-10, both from Yakult Honsha (Tokyo), and $0.1 \%(\mathrm{w} / \mathrm{v})$ pectolyase Y-23, from Seishin Pharmaceutical (Tokyo), dissolved in a washing solution of $0.9 \mathrm{M}$ sorbitol, $10 \mathrm{mM} \mathrm{CaCl} .2 \mathrm{H}_{2} \mathrm{O}$ and $5 \mathrm{mM}$ MES (2-morpholino-ethanesulfonic acid) at $\mathrm{pH} 5.6$ and incubated statically under dark conditions for $2 \mathrm{~h}$ at room temperature gave a high protoplast yield with the oriental hybrid lily cvs. 'Casablanca,' 'Siberia', and 'Acapulco'. The optimum combination of enzymes for protoplast isolation from Hypericum perforatum L. was 14\% cellulase $+1.5 \%$ pectinase $+1 \%$ macerozyme, $+0.5 \%$ driselase (Saker et al., 1999). Nagata and Takede (1984) succeeded in isolating of plant protoplasts from Nicotiana tobacum L. leaves using enzymes solution for maceration of leaves containing $0.1 \%$ pectolyase $\mathrm{Y}-23$ and $0.5 \%$ potassium dextran sulfate dissolved in $0.6 \mathrm{M}$ mannitol solution, and the $\mathrm{pH}$ was adjusted to 5.8 with $0.1 \mathrm{~N} \mathrm{HCL}$ (Fig. 1). Then, $1 \%$ cellulase solution which was dissolved in $0.6 \mathrm{M}$ manitol solution at $\mathrm{pH}=5.2$, was added to the enzyme solution. Also, they mentioned that this procedure yielded about $10^{7}$ protoplasts of palisade cells from $1 \mathrm{~g}$ fresh weight tobacco leaves. The optimum condition for protoplast isolation from vetiver was established by using $2 \%$ cellulase (Onozuka R10), 2\% macerozyme R10, $0.5 \%$ pectinase in $0.4 \mathrm{M}$ mannitol and $7 \mathrm{mM} \mathrm{CaCl}_{2} .2 \mathrm{H}_{2} \mathrm{O}$ at $\mathrm{pH} 5.8$ and incubated for 10 hours in the dark on the rotary shaker at 50 rpm (Prasertsongskun, 2004). Karim and Adachi (1997) reported the successful isolation and culture of protoplast of Allium cepa from cell suspension culture. The ANOVA for viability indicated effects at $p<0.01$ for cellulose and pectinase concentration, time and the interaction. Means comparison for protoplast viability showed that the treatment combinations of $4 \%$ cellulose, $0.2 \%$ pectinase and 24 $\mathrm{h}$ and $2 \%$ cellulose, $1 \%$ pectinase and $24 \mathrm{~h}$ gave the highest and lowest protoplast viabilities, respectively, as compared to all other treatments (Fig. 2).
As a general rule, as the hydrolytic enzyme concentration is increased, more active sites are available for the formation of enzyme-substrate complex (Rastogi, 2003). Hence, the number of viable protoplasts isolated tends to increase correspondingly. Accordingly, an increasing enzyme concentration contributes to an increase in the penetration of enzymes through multilayers of, for example, tightly packed callus cells (Rao and Prakash, 1995). Nonetheless, the cellulose and pectin layers of callus tissue cells may become saturated with enzymes if levels of cellulase and pectinase enzymes are in the order of $2.0 \%$ (Kremer and Wood, 1992). Thereafter, addition of more enzymes per unit volume is unable to further increase the numbers of viable protoplasts. Moreover, higher concentrations of enzymes may negatively influence the viability of protoplasts. This reduction in the yield is probably due to overdigestion of the protoplasts by pectinase and cellulase enzymes (Raiker et al., 2008).

The highest yield and viability was obtained from Anabias nana when protoplasts were digested from in vitro sixweek-old leaves with $2 \%$ cellulose Onozuka R $10,0.2 \%$ pectolyase $\mathrm{Y}-23,0.6 \mathrm{M}$ mannitol, $2 / 5 \mathrm{mM} \mathrm{CaCl}_{2} \cdot 2 \mathrm{H}_{2} \mathrm{O}$ and 5 mM MES [pH 5.6 for $4 \mathrm{~h}$ in the dark (Pongchawee et al., 2006)]. Zhang et al. (2011) reported the highest yield of more than $1.5 \times 10^{7}$ protoplasts $\mathrm{g}^{-1}$ fresh weight with more than $90 \%$ viability was consistently obtained from Carica papaya L. by optimised isolation conditions: enzyme combinations of $1.2 \%$ cellulose R10, $0.3 \%$ macerozyme R10 and $0.44 \mathrm{M} \mathrm{d}$-mannitol, $\mathrm{pH}=5.8$ and incubation for $13 \mathrm{~h}$ at $26^{\circ} \mathrm{C}$ in darkness (Zhang et al., 2011).

Ling et al. (2010) reported the highest amount of viable protoplasts $\left(1.75 \pm 0.68 \times 10^{4}\right.$ protoplasts/gr FW) was obtained from callus of Eurycoma longifolia when the sorbitol concentration was maintained at $0.5 \mathrm{M}$. The optimum enzyme concentration was found to be $1.5 \%(\mathrm{w} / \mathrm{v})$ of cellulase and pectinase in which $2.75 \pm 1.04 \times 10^{4}$ protoplasts/gr FW were isolated. Meanwhile, an incubation period of $3 \mathrm{~h}$ with enzyme solution resulted in the maximum yield of protoplasts $\left(5.58 \pm 1.46 \times 10^{4}\right.$ protoplasts $/ \mathrm{gr}$ FW). It's supposed that the observed difference between mentioned results can be because of species and kind of second used enzyme like pectolyase Y-23, which pectinase is used in our experiment instead.

Similarly, a high contact of isolated protoplasts to the centrifuge tubes walls in an increased time term of enzyme

Tab. 2. Analysis of variance on protoplast viability $(\% ; n=3)$ in Lilium ledeoborii

\begin{tabular}{ccccc}
\hline Source of variation & Df & MS & F & $p$ value \\
\hline Cellulase & 2 & 124.16 & 10.551 & 0.000 \\
Pectinase & 1 & 6.950 & 41.218 & 0.447 \\
Time & 1 & 485.039 & 1.886 & 0.000 \\
CellulasexPectinase & 2 & 22.198 & 2.034 & 0.166 \\
Cellulasextime & 2 & 23.930 & 0.038 & 0.146 \\
Pectinasextime & 1 & 0.448 & 5.146 & 0.846 \\
CellulasexPectinasextime & 2 & 60.561 & & 0.011 \\
\hline Error & 36 & 11.768 & & \\
\hline
\end{tabular}



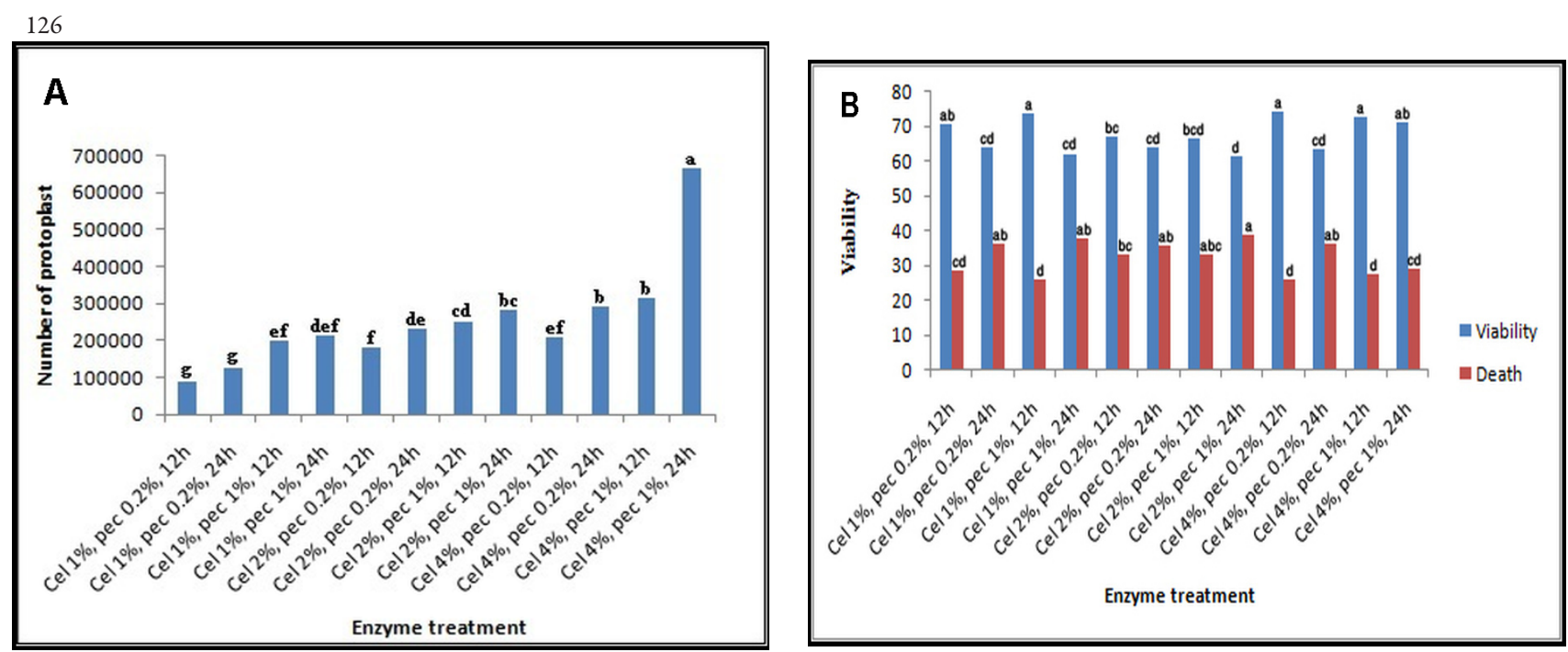

Fig. 1. (A) The mean numbers $(\mathrm{n}=3$ ) of isolated protoplasts from Lilium ledeouborri leaf mesophyll tissue treated for 12 or $24 \mathrm{~h}$ with various different enzyme ( $\mathrm{Cel}=$ cellulase; $\mathrm{Pec}=$ pectinase $)$ cocktail concentrations of cell wall hydrolytic enzymes. Different letters indicate a significant difference at the $p \leq 0.05$ level. (B) The mean viability ( $\% ; \mathrm{n}=3$ ) of protoplasts isolated from Lilium ledeoborii leaf mesophyll tissue treated for 12 or $24 \mathrm{~h}$ with various different enzyme $(\mathrm{Cel}=$ cellulase; $\mathrm{Pec}=$ pectinase $)$ cocktail concentrations of cell wall hydrolytic enzymes. Different letters indicate a significant difference at the $p \leq 0.05$ level.
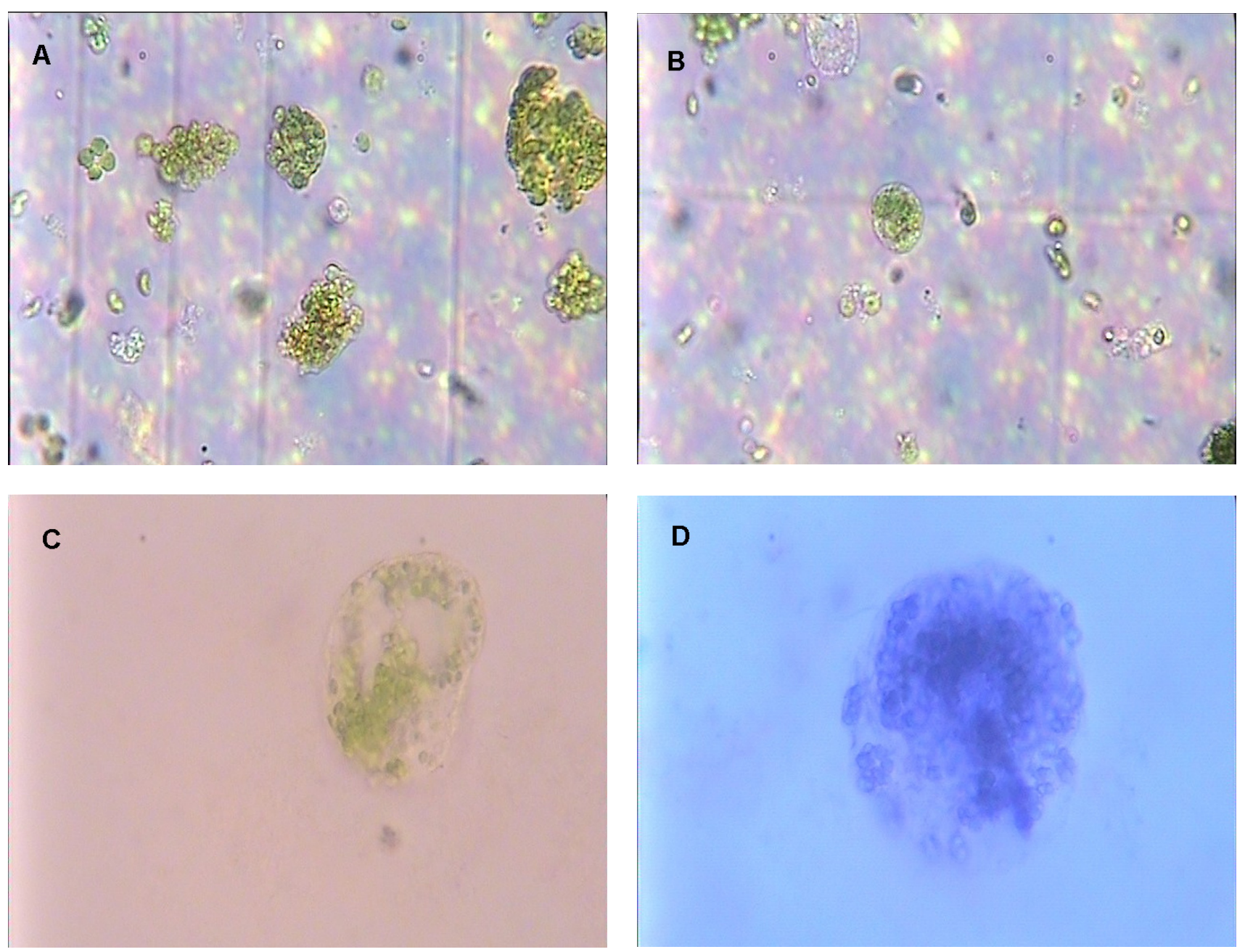

Fig. 2. Protoplasts produced by cell wall hydrolytic enzyme treatments of Lilium ledouborri mesophyll tissue. (A) $4 \%$ cellulase and $1 \%$ pectinase for $24 \mathrm{~h}$. (B) $1 \%$ cellulase and $0.2 \%$ pectinase for $12 \mathrm{~h}$. (C) viable protoplast. (D) dead protoplast coloured by trypan blue. 
treatment had eventually reduced the number of viable protoplasts in the protoplast isolation of Crocus sativus L. (Darvishi et al., 2006). In contrast, a digestion period of up to $20 \mathrm{~h}$ resulted in the best yield of protoplasts $\left(9.45 \times 10^{5}\right.$ protoplasts/g FW) from the callus tissue of the nitrogen fixing woody plant, Robinia pseudoacacia (Kanwar et al., 2009). It's concluded that, the best treatment for isolation of Lilium protoplast was $4 \%$ cellulase and $1 \%$ pectinase for $24 \mathrm{~h}$.

\section{References}

Assani A, Haicour R, Wenzel G, C^ote F, Bakry F, ForoughiWehr B, Ducreux G, Aguillar M-E, Grapin A (2001). Plant regeneration from protoplasts of dessert banana cv. 'Grande Naine' (Musa spp., Cavendish sub-group AAA) via somatic embryogenesis. Plant Cell Rep 20:482-488

Azad MAK, Yokota S, Ishiguri F, Yoshizawa N (2006). Plant regeneration from mesophyll protoplasts of a medicinal plant, Phellodendron amurense Rupr. In vitro Cellular Dev. Biol Plant 42(6):502-507.

Arnalte E, Perez P, Segura J, Cornejo M (1991). Protoplast isolation from Digitalis obscura microspores. Physiologia plant 82:1

Darvishi E, Zarghami R, Mishani CA, Omidi M, Sarkhosh A (2006). Investigation of the best time of enzyme treatment in order to isolate the protoplast from embryogenic callus to saffron (Crocus sativus L.). Biotechnology 5(3):284-286.

Duquenne B, Eeckhaut T, Werbrouck S, Huylenbroeck JV (2007). Effect of enzyme concentrations on protoplast isolation and protoplast culture of Spathiphyllum and Anthurium. Plant Cell, Tissue Organ Cult 91(2):165-173.

Davey MR, Anthony P, Power JB, Lowe KC (2000). Plant protoplasts, 1034-1042 p. In: Spier RE (Ed.). Encyclopaedia of Cell Technology. John Wiley and Sons, New York, USA.

Dulieu HL, Bruneau R, Pelletier A (1983). Heritable differences in in vitro regenerability in Petunia at the protoplast and at the seedling stage, 236-237 p. In: PotryLus CT, Harms A, Hutter R, King PJ, Shillito RD (Eds.). Protoplasts 1983, Birhauser, Basel.

Frearson EM, Power JB, Cocking EC (1973). The isolation, culture and regeneration of Petunia leaf protoplasts. Dev Biol 33:130-137.

Galbraith DW, Afonso CL, Harkins KR (1984). Flow sorting and culture of protoplasts: Conditions for high-frequency recovery, growth and morphogenesis from sorted protoplasts of suspension cultures of Nicotiana. Plant Cell Rep 3:151155.

Horita M, Moorhashi H, Komai F (2004). Production of fertile somatic hybride plants between oriental hybrid lily and Lilium $\times$ formolongi. Planta 217:597-601.

Hayward C, Power BJ (1975) Plant production from leaf protoplasts of Peomiaparodii. Plant Sci. Lett 4: 407-410.

Izhar S, Power JB (1977). Genetical studies with Petunia leaf protoplasts 1. Genetic variation to specific growth hormones and possible genetic control on stages of protoplast development in culture. Plant Sci Lett 8:375-383

Kremer SM, Wood PM (1992). Continuous monitoring of cellulose action on microcrystalline cellulose. Appl Microbiol Biotechnol 37(6):750-755.

Khosh-khui M, Azadis P (2007). Micropropagation of Lilium ledebourii (Baker) Boiss as affected by plant growth regulator, sucrose concentration, harvesting season and cold treatments. Electr J Biotechnol ISSN: 0717-3458.

Karim MA, Adachi T (1997). Cell suspension, isolation and culture of protoplasts of Allium cepa. Plant Cell Tissue Organ Cult 51:43-47.

Kanwar K, Bhardwaj A, Deepika R (2009).Efficient regeneration of planlets from callus and mesophyll derived protoplast of Robinia pseudoacacia L. Plant Cell, Tissue Organ Cult 96:95-103.

Kuchuk N, Herrmann RG, Koop H-U (1998). Plant regeneration from leaf protoplasts of evening primrose (Oenothera hookeri). Plant Cell Rep 17:601-604.

Ling APK, Phua GAT, Tee CS, Hussein S (2010). Optimazation of protoplast isolation protocols from callus of Eurycoma longifolia. J of Med Plants Res 4(17):1778-1785.

Nagao T (1982). Somatic hybridization by fusion of protoplast. J Crop Sci 51:35-42.

Nagata T, Takede H (1984). Isolation and culture of protoplast tobacco, 328-337 p. In: Vasil L (Ed.). Cell Culture and Somatic Cell Genetic of Plants, Academic Press, New York - London.

Pongchawee K, Na-nakorn U, Lamseejan S, Poompuang S, Phansiri $S$ (2006). Factors affecting the protoplast isolation and culure of Anabias nana Engler. T O Botany 2:193-200.

Power JB, Frearson E, Hayward D, George D, Evans F, Berry S, Cocking E (1976). Somatic hybridization of Petunia hybrida and Petunia parodii. Nature 263:500-502.

Power JB, Berry FS, Chapman VJ, Cocking CE (1980). Somatic hybridization of sexually incompatible Petunia parodii, Petunia parviflora. Theor Appl Genet 57:1-4.

Power JB, Davey MR, Anthony P, Lowe CK (2004). Protoplast culture and regeneration, 1065-1068 p. In: Goodman RM (Ed.). Encyclopaedia of Plant and Crop Science, Marcel Dekker, New York, USA.

Prasertsongskun S (2004). Isolation and culture of suspension protoplasts of vetiver. Sci Technol 26(3):411-416.

Rao KS, Prakash AH (1995). A simple method for the isolation of plant protoplasts. J Biosci 20(5):645-655.

Raikar SV, Braun RH, Bryant C, Conner AJ, Christey MC (2008). Efficient isolation, culture and regeneration of Lotus corniculatus protoplast. Plant Biotrchnol Rep 2(3):171177.

Rao KS, Prakash AH (1995). A simple method for the isolation of plant protoplasts. J Biosci 20(5):645-655.

Rastogi SC (2003). Cell and Molecular Biology. United states 
128

of America: New Age International.

Rasheed JH, Al-Mallah MK, Cocking EC, Davey MR (1990). Root hair protoplasts of Lotus corniculatus L. (birdsfoot trefoil) express their totipotency. Plant Cell Rep 8:565-569.

Sink KC, Power BJ (1977). The isolation, culture and regeneration of leaf protoplasts of Petunia parviflora Juss. Plant Sci Lett 10:335-340.

Stephen C (1995). Protoplast isolation and culture, 167-180 p. In: Gamborg G, Phillips A (Eds.). Plant Fundemental Methods Springer -Verlag Berlin-Heidelberg.

Sink KC, Power BJ (1977). The isolation, culture and regeneration of leaf protoplasts of Petunia parviflora Juss. Plant Sci Lett 10:335-340.

Saito A, Suzuki M (1999). Plant regeneration from meristemderived callus protoplasts of apple (Mulus $\times$ domestica cv.'Fuji'). Plant Cell Rep 18:549-553.

Saker SS, Neuman KH, Badawy EM, El-bahr MK, Taha HS (1999). Isolation and culturing of protoplasts from Hypericum perforatum L. Arab J Biotech 2:227-234.

Sinha A, Wetten AC, Caligari PDS (2003). Effect of biotic factors on the isolation of Lupinus albus protoplasts. Aust J Bot 51:103-109.
Torres K (1988). Isolation and culture of protoplasts from carrot cell suspension cultures, 187-200 p. In: Torres K (Ed.). Tissue culture techniques for horticultural crops, Academic Press, New York.

Vasil V, Vasil KI (1974). Regeneration of tobacco and Petunia plants from protoplasts and culture of corn protoplasts. In vitro 10:83-96.

Umate P, Rao KV, Kiranmayee K, Sree TJ, Sadanandam A (2005). Plant regeneration of mulberry (Morus indica) from mesophyll-derived protoplasts. Plant Cell, Tissue Organ Cult 82(3):289-293.

Van Tuyl JM, Straathof TP, Bino RJ, Kwakkenbos AAM (1988). Effect of three pollination methods on embryo development and seed set in intra- and interspecific crosses between seven Lilium species. Sex Plant Reprod 1:119-123.

Wendelbo P (1977). Tulips and irises of Iran and their relatives. Botanical Institute of Iran, Tehran. 